\title{
Fluoride Application
}

\section{Reham Saad*}

Department of Oral and Dental Medicine, Ministry of Health and Population of Egypt, Egypt

*Corresponding Author: Reham Saad, Department of Oral and Dental Medicine, Ministry of Health and Population of Egypt, Egypt.

Topical fluorides are applied directly to the tooth enamel. For examples include fluoride toothpastes and mouthwashes as well as fluoride application by the dentist.

Systemic fluorides are those that are swallowed to the entire body. Examples include fluoridated water and dietary fluoride supplements.

The best result to reduce dental caries is achieved by fluoride application topically and systemically.

Dentists use topical fluoride application to protect the oral health of children and adults, especially patients who are at a higher risk of developing caries.

Some factors that may increase a person's risk of developing caries include the following:

- Poor oral hygiene.

- High levels of caries-causing bacteria in the mouth.

- Decreased salivary flow, resulting in dry mouth.

- Eating disorders.

- Drug or alcohol abuse.

- Lack of regular professional dental care.

- Exposed root surfaces of teeth.

- Poor diet.

- Tooth enamel defects.

- Undergoing head and neck radiation therapy.

\section{Topical fluoride treatment:}

The fluoride obtained in many forms such as solution, gel, foam or varnish.

\section{Methods of fluoride application}

Varnish and solution forms are applied with a cotton swab or brush it takes few minutes.

Gel and foam forms are applied in a tray that is held in the mouth for several minutes.
Received: February 27, 2020

Published: March 01, 2020

(C) All rights are reserved by Reham Saad.
Children at higher risk of tooth decay receive 2 fluoride treatments a year and fissure sealants on their first and second permanent molars (Figure 1).

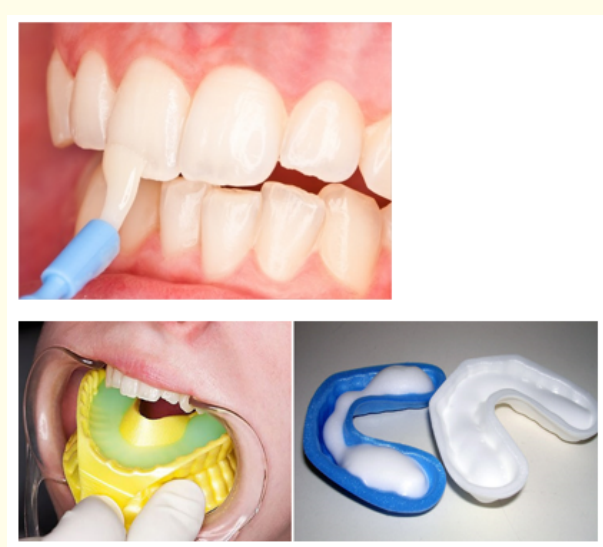

Figure 1

\section{Assets from publication with us}

- Prompt Acknowledgement after receiving the article

- Thorough Double blinded peer review

- Rapid Publication

- Issue of Publication Certificate

- High visibility of your Published work

Website: https://www.actascientific.com/

Submit Article: https://www.actascientific.com/submission.php Email us: editor@actascientific.com

Contact us: +919182824667 